\title{
The Prevalence of Insomnia Symptoms and Its Association With Quality of Life Among Clinically Stable Older Patients With Psychiatric Disorders in China During the COVID-19 Outbreak
}

Research

Keywords:

Posted Date: February 8th, 2021

DOl: https://doi.org/10.21203/rs.3.rs-95735/v2

License: (1) This work is licensed under a Creative Commons Attribution 4.0 International License. Read Full License 


\section{Abstract}

The authors have requested that this preprint be withdrawn due to erroneous posting.

\section{Full Text}

The authors have withdrawn this preprint from Research Square. 